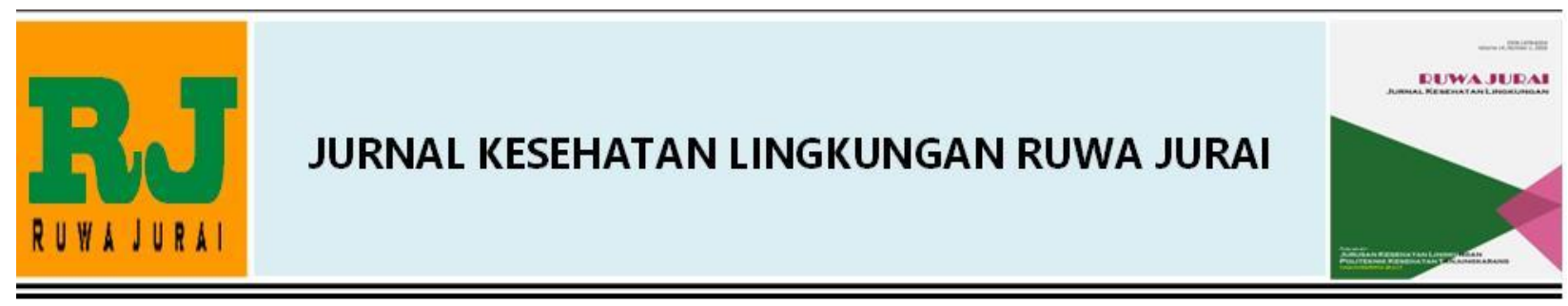

\title{
PEMANFAATAN AMPAS TEBU SEBAGAI ARANG AKTIF DENGAN AKTIVATOR LARUTAN BELIMBING WULUH (Averrhoa bilimbi L.)
}

\author{
Anisa Kurniasih ${ }^{1 *}$, Dina Audia Pratiwi ${ }^{2}$, Muhammad Amin ${ }^{3}$ \\ ${ }^{1}$ Puskesmas Permata Sukarame Kota Bandar Lampung \\ 2 Dinas Lingkungan Hidup Kota Bandar Lampung \\ ${ }^{3}$ Balai Penelitian Teknologi Mineral-LIPI Lampung
}

\section{Artikel Info : \\ Received 21 September 2020 Accepted 30 Desember 2020 Available online 31 Desember 2020}

Editor: Mei Ahyanti

Key word :

Activated carbon, sugarcane bagasse, Averrhoa bilimbi L

Kata Kunci :

Arang aktif, ampas tebu, belimbing wuluh, Averrhoa bilimbi $L$

\begin{abstract}
A bstract
One of the efforts to utilize bagasse is activated carbon which can be used as an adsorbent for the pharmaceutical industry, foodstuffs, and water purification to remove odors, tastes and colors. So far, the raw materials for making activated carbon use coal and coconut shells, while the activator uses chemicals such as $\mathrm{KOH}, \mathrm{NaOH}, \mathrm{H} 2 \mathrm{SO} 4, \mathrm{HCl}$, and others. The manufacture of activated carbon is carried out in three stages, namely the process of dehydration, carbonization, and activation. Bagasse that has been dehydrated for 2 days using sunlight, is carbonized for 1 hour at a temperature of $450^{\circ} \mathrm{C}$. Carbon is activated using starfruit extract with a ratio of extract: distilled water, $100 \%: 0 \%, 75 \%: 0 \%, 50 \%: 505,25 \%: 75 \%$, and the time is varied, namely for 4 hours, 8 hours, 16 hours, and 24 hours. From the research results as much as 4.000 grams of bagasse carbonized to produce 170 grams of carbon. The results of the analysis of the proximate content in bagasse activated carbon have met the Indonesian National Standard (SNI 06-3730-1995), namely the best Total Moisture Content of 2.88\%, the best Volatile Matter of $6.88 \%$. The best ash was $3.11 \%$. The best-fixed carbon was $86.30 \%$. The iodine number produced from the bagasse activated carbon is $937.9686 \mathrm{mg} / \mathrm{g}$. The lodine number has met the requirements of the Indonesian Industry Standard (SII 0258-88), which is more than $750 \mathrm{mg} / \mathrm{g}$, indicating that the activation of activated carbon using starfruit is very reactive. Starfruit can be used as an environmentally friendly activator in making activated carbon.
\end{abstract}

Upaya mendayagunakan ampas tebu salah satunya dengan pembuatan arang aktif yang dapat digunakan sebagai adsorben untuk keperluan industri obat-obatan, bahan makanan, dan penjernih air. Selama ini bahan baku pembuatan arang aktif menggunakan batu bara dan batok kelapa sedangkan aktivatornya menggunakan bahan- kimia seperti $\mathrm{KOH}, \mathrm{NaOH}$, $\mathrm{H}_{2} \mathrm{SO}_{4}, \mathrm{HCl}$ dan lain-lain. Pembuatan arang aktif dilakukan dengan tiga tahap, yaitu proses dehidrasi, karbonisasi, dan aktivasi. Ampas tebu yang telah dilakukan proses dehidrasi selama 2 hari menggunakan terik matahari, dikarbonisasi selama 1 jam dengan suhu $450^{\circ} \mathrm{C}$. Arang diaktivasi menggunakan ekstrak belimbing wuluh dengan perbandingan ekstrak: aquades, 100\% : 0\%, 75\% : 0\%, 50\%: 505, 25\%: 75\% dan waktu divariasikan yaitu selama 4 jam, 8 jam, 16 jam, dan 24 jam. Dari hasil penelitian sebanyak 4.000 gram ampas tebu yang di karbonisasi menghasilkan $170 \mathrm{gram}$ arang. Hasil analisis kandungan proximat pada arang aktif ampas tebu telah memenuhi Standar Nasional Indonesia (SNI 06-37301995) yaitu kadar Moisture Total terbaik sebesar 2,88\%, Volatile Matter terbaik sebesar 6,88\%. Ash terbaik sebesar 3,11\%. Fixed Carbon terbaik sebesar 86,30\%. Bilangan lodium yang dihasilkan dari arang aktif ampas tebu tersebut adalah 937,9686 mg/g. Bilangan iodin telah memenuhi syarat Standar Industri Indonesia (SII 0258-88) yaitu lebih dari 750 mg/g, menunjukan bahwa pengaktifan arang aktif menggunakan buah belimbing wuluh sangat reaktif. Belimbing wuluh dapat digunakan sebagai aktivator yang ramah lingkungan pada pembuatan karbon aktif.
Ruwa Jurai: Jurnal

Kesehatan Lingkungan is licensed under a Creative Commons Attribution-NonCommercial 4.0 International License.

\footnotetext{
* Corresponding author: Anisa Kurniasih

J. Sebuku No. 6/13 Tanjungk Baru, Bandar Lampung, Provinsi Lampung Email : anisakurniasih49@gmail.com
} 


\section{PENDAHULUAN}

Indonesia merupakan negara yang kaya akan sumber daya air. Ketersediaan air bersih di Indonesia mencapai $15.500 \mathrm{~m}^{3}$ per kapita per tahun, masih jauh dari ketersediaan air ratarata dunia ( $8.000 \mathrm{~m}^{3} /$ tahun). Meskipun begitu, Indonesia masih mengalami kelangkaan air bersih. Saat ini sekitar 119 juta orang di Indonesia tidak mempunyai askes langsung terhadap air bersih, lebih dari $70 \%$ total penduduk tergantung pada air yang diambil dari sumber yang telah terakomondasi (Gita, 2012; Prihatin, 2013). Air yang terakomondasi dapat membawa penyakit seperti diare.

Dalam situasi seperti ini, diperlukannya proses penjernihan air dengan menggunakan filtrasi dengan adsorben. Adsorben yang selama ini digunakan yaitu arang aktif karena memiliki luas permukaan yang tinggi sehingga kemampuan adsorpsinya besar (Bansal et al., 1990; Purwonugroho, 2013).

Berbagai penelitian telah dilaksanakan untuk meningkatkan kualitas air bersih dengan memanfaatkan arang aktif yang dibuat dari bahan limbah seperti tongkol jagung, batang gumintir maupun tempurung kelapa (Dedy, 2010; Rizkyi et al., 2016; Suhendra dan Gunawan, 2011). Bahan-bahan tersebut digunakan karena mengandung lignoselulosa (Sahara et al., 2017).

Salah satu material alternatif yang banyak mengandung lignoselulosa adalah ampas tebu atau baggase merupakan limbah hasil pengolahan tebu menjadi gula (Edhi, 2005; Thomas, 2007). Di Provinsi Lampung banyak terdapat pabrik pengolahan tebu menjadi gula menghasilkan limbah ampas tebu sekitar 4.000 sampai 6.000 ton per hari. Limbah tersebut selama ini hanya dimanfaatkan sebagai bahan bakar pabrik, ditambah lagi limbah ampas tebu yang dihasilkan oleh pedagang tebu dikaki lima (Amie dan Nugraha, 2014; Evival, 2018).

Untuk membuat arang aktif biasanya menggunakan $\mathrm{KOH}, \mathrm{NaOH}, \mathrm{H}_{3} \mathrm{PO}_{4}, \mathrm{H}_{2} \mathrm{SO}_{4}, \mathrm{HCl}$ dan lain-lain sebagai aktivatornya. Penggunaan bahan kimia tersebut beresiko menimbulkan masalah pencemaran lingkungan (Susanti, 2005). Buah belimbing wuluh (Averrhoa bilimbi L.) adalah salah satu buah yang banyak mengandung senyawa asam alifatik, asam heksadekanoat, asam (Z)-9-oktadekanoat, feroxida dan sulfat (Reza et al., 2013). Senyawasenyawa tersebut sangat diperlukan karena reaktif terhadap oksigen pada saat pengaktifan arang. Tujuan penelitian adalah memberikan wawasan bagi peneliti bagaimana cara pembuatan arang aktif dari ampas tebu menggunakan aktivator belimbing wuluh (Averrhoa bilimbi L) dan memanfaatkan serta mengurangi limbah ampas tebu.

\section{METODE}

Eksperimen pembuatan arang aktif menggunakan bahan baku ampas tebu yang berasal dari pedagang tebu di kaki lima serta belimbing wuluh (Averrhoa bilimbi L.) sebagai aktivator. Bahan kimia yang digunakan sebagai bahan uji daya serap arang aktif adalah aquades, larutan iodium, $\mathrm{KI}, \mathrm{Na}_{2} \mathrm{~S}_{2} \mathrm{O}_{3}$, dan larutan amilum.

Penelitian dilaksanakan di Laboratorium Kesehatan Lingkungan Politeknik Kesehatan, menggunakan disain percobaan faktorial, yang disusun dalam Rancangan Acak Lengkap (RAL), terdiri dari 2 faktor. Perbandingan konsentrasi aktivator ekstrak belimbing wuluh : aquadest $(a=$ $100 \%: 0 \% ; b . b=75 \%: 25 \% ; c=50 \%: 50 \% ; d=$ 25\% : 75\%) dan waktu aktivasi $(a=4$ jam; $b=8$ jam; $c=16$ jam; $d=24$ jam). Rancangan perlakuan yang digunakan adalah faktorial $4 \times 4$. Kombinasi perlakuan sebanyak 16 .

\section{HASIL}

Hasil analisis kandungan proximat pada arang aktif ampas tebu disajikan pada Tabel 1. Karbon yang terdapat dalam arang ampas tebu sebelum perlakuan cukup tinggi yaitu $71,09 \%$. Setelah proses karbonisasi, dari 4.000 gram ampas tebu diperoleh arang aktif sebanyak 170 gram arang, atau tingkat perolehan 4,25\%.

Hasil analisis proximat arang ampas tebu pada Tabel 1 menunjukkan kadar air kurang dari $15 \%$, zat menguap kurang dari $25 \%$, karbon terikat lebih dari $65 \%$, sedangkan kadar abu belum memenuhi standar, yaitu kurang dari $10 \%$. Kadar air tertinggi dihasilkan oleh arang aktif pada konsentrai ekstrak belimbing wuluh $25 \% \mathrm{~m} / \mathrm{v}$ dan lama aktifasi 16 jam yaitu 5,75\%. Sedangkan kadar air terendah dihasilkan oleh arang aktif pada konsentrasi ekstrak belimbing wuluh $75 \% \mathrm{~m} / \mathrm{v}$ dan lama 
aktifasi 4 jam yaitu 2,88\%. Rata-rata kadar air saat penggunaan konsentrasi ekstrak 25\% kadar air sebesar 4,68\%, sedangkan pada konsentrasi ekstrak 50\% kadar air turun menjadi $3,61 \%$ dan pada konsentrasi ekstrak $100 \%$ naik kembali menjadi $3,87 \%$.

Tabel 1. Hasil Analisis Kandungan Proximat Pada Arang Aktif Ampas Tebu

\begin{tabular}{|c|c|c|c|c|c|c|}
\hline \multirow[b]{2}{*}{$\begin{array}{l}\text { No. } \\
\text { Sample }\end{array}$} & \multirow[b]{2}{*}{$\begin{array}{l}\text { Konsentrasi Ekstrak(\%) } \\
\text { / Lama Aktivasi (Jam) }\end{array}$} & \multicolumn{5}{|c|}{ Hasil Analisis (\%) } \\
\hline & & $\begin{array}{l}\text { Moisture } \\
\text { Total }\end{array}$ & $\begin{array}{l}\text { Inhernt } \\
\text { Moisture }\end{array}$ & $\begin{array}{l}\text { Volatile } \\
\text { Matter }\end{array}$ & Ash & $\begin{array}{l}\text { Fixed } \\
\text { Carbon }\end{array}$ \\
\hline $1 \mathrm{~A}$ & $100 / 4$ & 3,88 & 0,04 & 6,88 & 9,02 & 84,06 \\
\hline $1 \mathrm{~B}$ & $100 / 8$ & 2,96 & 0,05 & 8,04 & 9,46 & 82,45 \\
\hline $1 \mathrm{C}$ & $100 / 16$ & 3,62 & 0,06 & 8,42 & 9,21 & 82,45 \\
\hline $1 \mathrm{D}$ & $100 / 24$ & 5,05 & 0,05 & 7,94 & 9,04 & 82,97 \\
\hline $2 \mathrm{~A}$ & $75 / 4$ & 2,88 & 0,07 & 9,98 & 4,97 & 84,98 \\
\hline $2 B$ & $75 / 8$ & 3,44 & 0,04 & 10,26 & 5,57 & 84,13 \\
\hline $2 C$ & $75 / 16$ & 3,00 & 0,05 & 10,54 & 5,59 & 83,47 \\
\hline $2 \mathrm{D}$ & $75 / 24$ & 5,13 & 0,07 & 10,76 & 5,58 & 83,59 \\
\hline $3 A$ & $50 / 4$ & 4,97 & 0,06 & 15,68 & 8,30 & 75,96 \\
\hline $3 B$ & $50 / 8$ & 5,61 & 0,04 & 14,98 & 8,16 & 76,82 \\
\hline $3 C$ & $50 / 16$ & 3,84 & 0,03 & 15,79 & 7,62 & 76,56 \\
\hline $3 \mathrm{D}$ & $50 / 24$ & 3,97 & 0,05 & 14,54 & 7,62 & 77,79 \\
\hline $4 \mathrm{~A}$ & $25 / 4$ & 5,22 & 0,07 & 15,95 & 3,11 & 80,87 \\
\hline $4 \mathrm{~B}$ & $25 / 8$ & 3,87 & 0,04 & 16,77 & 3,22 & 79,97 \\
\hline $4 C$ & $25 / 16$ & 5,75 & 0,05 & 16,00 & 3,14 & 80,75 \\
\hline 4D & 25 / 24 & 3,89 & 0,05 & 15,77 & 3,27 & 80,91 \\
\hline
\end{tabular}

Dari Gambar 1 dapat dilihat secara hitungan rata-rata konsentrasi $100 \%$ yaitu $924,16 \mathrm{mg} / \mathrm{g}$, daya serap iodium lebih baik dibandingkan dengan konsentrasi ekstrak 25\%, 50\%, dan $75 \%$. Kadar daya serap iodium tertinggi saat aktivasi 4 jam, sehingga waktu aktivasi tidak perlu sampai 24 jam. Kenaikan daya serap iodium seiiring dengan kenaikan konsentrasi ekstrak belimbing wuluh.

Hasil statistik menunjukkan bahwa perlakuan konsentrasi terbaik diperoleh pada konsentrasi 100\% untuk Moisture dengan mean 3,87\% (2,96-5,05\%). Pada Inhern Moisture konsentrasi terbaik diperoleh pada konsentrasi $50 \%$ dengan mean $0,45 \%$ dengan minimum $0,3 \%$ dan maksimum $0,6 \%$. Untuk Volatile Matter konsentrasi terbaik diperoleh pada konsentrasi $100 \%$ dengan mean $7,82 \%$ dengan minimum $6,88 \%$ dan maksimum $8,42 \%$. Pada Ash konsentrasi terbaik diperoleh pada konsentrasi $25 \%$ dengan mean 3,18\% dengan minimum $3,1 \%$ dan maksimum $3,27 \%$. Untuk Fixed Carbon konsentrasi terbaik diperoleh pada konsentrasi $100 \%$ dengan mean $85,36 \%$ dengan minimum $84,75 \%$ dan maksimum $86,30 \%$. Dari hasil tersebut menunjukan ada pengaruh konsentrasi terhadap arang aktif.

Pada waktu aktivasi, Moisture Total terbaik diperoleh pada waktu aktivasi selama 8 jam dengan mean 3,97\% (2,96-5,61\%). Untuk Inhern Moisture diperoleh pada waktu aktivasi selama 8 jam dengan mean 0,42\% (0,4-0,5\%). Pada Volatile Matter waktu aktivasi terbaik diperoleh pada waktu aktivasi 4 jam dengan mean 12,12\% (6,88-15,95\%). Untuk Ash waktu aktivasi terbaik diperoleh pada waktu aktivasi 8 jam dengan mean 5,64\% (3,22-8,16\%). Pada Fixed Carbon waktu aktivasi terbaik terdapat pada waktu aktivasi 4 jam dengan mean 81,84\% (75,96-85,57\%). Dari hasil tersebut terlihat bahwa tidak ada pengaruh waktu aktivasi terhadap arang aktif.

Pada Kruskal-Wallis Test, untuk variasi konsentrasi ekstrak terbaik, pada Moisture Total adalah pada konsentrasi $75 \%$ dengan mean $5,25 \%$. Untuk Inhern terdapat pada konsentrasi ekstrak 50\% dengan mean 6.38\%. Pada Volatile Matter terdapat pada konsentrasi ekstrak 100\% dengan mean 2,50\%. Untuk Ash terdapat pada konsentrasi ekstrak $25 \%$ dengan mean 2,50\%. Pada Fixed Carbon konsentrasi terdapat pada konsentrasi ekstrak $100 \%$ dengan mean $14 \%$. Hasil analisis secara statistik menunjukan ada pengaruh konsentrasi terhadap arang aktif.

Pada Kruskal-Wallis Test, untuk variasi waktu aktivasi terbaik, pada Moisture Total terdapat pada waktu aktivasi 8 jam dengan mean $7 \%$. Untuk Inhern waktu aktivasi terdapat pada 8 
jam dengan mean 4,75\%. Pada Volatile Matter terdapat pada waktu aktivasi 4 jam dengan mean $7,75 \%$. Untuk Ash terdapat pada waktu aktivasi 8 jam dengan mean $8 \%$. Pada Fixed
Carbon terdapat pada waktu aktivasi 4 jam dengan mean 9,25\%. Dari hasil tersebut terlihat bahwa tidak ada pengaruh waktu aktivasi terhadap arang aktif.

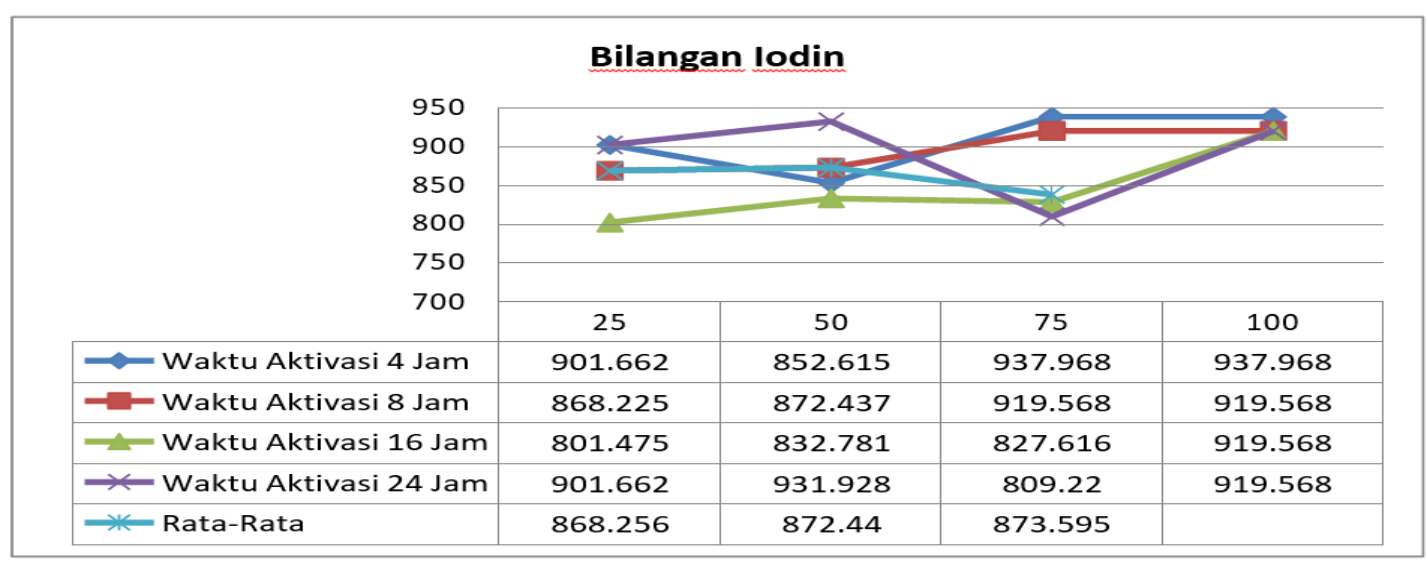

Gambar 1. Konsentrasi Aktivator dan Waktu Aktivasi Terhadap Daya Serap lodium

\section{PEMBAHASAN}

Adsorben diperlukan dalam menyerap logam-logam berat yang terdapat di dalam air seperti besi ( $\mathrm{Fe}$ ), Mangan ( $\mathrm{Mn}$ ), Cadmium (Cd) dan lain-lain (Khimayah, 2015; Utassia et al., 2015). Adsorben akan memiliki kadar efisiensi yang tinggi karena adanya kombinasi media filter yang diterapkan dalam satu reaktor yaitu media karbon aktif, zeolite dan pasir silica (Al Kholif et al., 2020; Rasman dan Saleh, 2016). Penelitian ini menggunakan bahan ampas tebu untuk membuat arang aktif yang diaktivasi menggunakan ekstrak belimbing wuluh. Penelitian Fahrurozi membuktikan bahwa belimbing wuluh efektif menurunkan kekeruhan pada air (Fahrurozi et al., 2015).

Hasil penelitian mendapatkan semakin kecil kadar air maka akan semakin baik kualitas arang aktif tersebut. Sedangkan semakin besar kadar air maka semakin banyak pori arang aktif yang tertutup oleh air. Hal ini menyebabkan daerah penyerapan pada permukaan arang aktif semakin kecil sehingga daya adsorbsinya semakin kecil. Kadar air tertinggi dihasilkan oleh arang aktif pada konsentrasi ekstrak belimbing wuluh $25 \% \mathrm{~m} / \mathrm{v}$ dan lama aktifasi 16 jam yaitu 5,75\%. Sedangkan kadar air terendah dihasilkan oleh arang aktif pada konsentrasi ekstrak belimbing wuluh $75 \%$ $\mathrm{m} / \mathrm{v}$ dan lama aktifasi 4 jam yaitu 2,88\%. Dari semua parameter yang divariasikan, kadar airnya memenuhi syarat Standar Industri Indonesia (SII 0258-88), yaitu kadar air maksimal 15\% untuk jenis serbuk (Standar Industri Indonesia, 1988).

Hasil rata-rata kadar air saat penggunaan konsentrasi ekstrak 25\% kadar air sebesar $4,68 \%$, sedangkan pada konsentrasi ekstrak $50 \%$ kadar air turun menjadi 3,61\% dan pada konsentrasi ekstrak $100 \%$ naik kembali menjadi $3,87 \%$. Hal ini disebabkan semakin sedikit ekstrak belimbing wuluh maka perbandingan penggunaan aquades lebih banyak yang mengakibatkan kadar air yang terkandung dalam arang aktif semakin tinggi. Tingginya kadar air dikarenakan banyak air yang terperangkap di dalam pori-pori arang aktif.

Dari hasil penelitian, arang aktif dengan kadar volatile matter tertinggi dihasilkan oleh aktivasi dengan konsentrasi ekstrak belimbing wuluh $25 \%$ dan waktu aktivasi 8 jam yaitu $16,77 \%$. Dari semua parameter yang divariasikan, kadar volatile matter memenuhi syarat Standar Industri Indonesia (SII 0258-88), yaitu kadar volatile matter maksimal $25 \%$ untuk jenis serbuk. Pada Tabel 1 tampak, semakin tinggi konsentrasi ekstrak maka semakin turun kandungan volatile matter pada arang aktif. Hal ini dikarenakan semakin tinggi konsentrasi ekstrak belimbing wuluh maka jumlah gas yang mudah menguap pada saat aktivasi semakin meningkat. Jadi seiring dengan 
peningkatan konsentrasi ekstrak belimbing wuluh, senyawa-senyawa yang terkandung pada arang bereaksi dengan ekstrak belimbing wuluh membentuk senyawa hidrogen, oksigen, nitrogen, dan sulfur dalam bentuk gas. Sedangkan gas-gas tersebut ketika mengalami pemanasan saat proses aktivasi suhu $600^{\circ} \mathrm{C}$ mengalami penguapan. Hal inilah yang menyebabkan kadar volatile matter yang terkandung didalam arang aktif menjadi sedikit.

Kadar abu menunjukan banyaknya sisa senyawa anorganik yang ada dalam arang aktif yang masih ditinggalkan dari proses pembakaran (silika dan kapur), sedangkan senyawa organiknya telah menguap pada proses pengaktivan. Kadar abu yang tinggi disebabkan oleh beberapa faktor, yaitu senyawa anorganik (logam-logam) yang tidak bereaksi dengan aktivator, sisa aktivator yang tidak larut dalam pencucian, dan sifat aktivator yang merusak struktur arang. Kadar abu yang dihasilkan merupakan pengotor arang aktif, kadar abu ini mempengaruhi reaktivitas arang aktif (Yulianti et al., 2010).

Dari hasil penelitian kadar abu terendah diperoleh pada konsentrasi ekstrak $25 \%$ dengan waktu aktivasi 4 jam yaitu, 3,11\%. Sedangkan untuk arang aktif dengan kadar abu tertinggi terdapat pada konsentrasi ekstrak $50 \%$ denganwaktu aktivasi 4 jam, yaitu 8,30\%. Berdasarkan hasil penelitian diketahui bahwa kadar abu arang aktif yang dihasilkan telah memenuhi Standar Industri Indonesia (SII 025888), yaitu kadar abu tidak lebih dari $10 \%$ berat jenis serbuk. Standar Industri Indonesia (SII 0258-88) digunakan sebagai acuan standar kualitas dari pembuatan arang aktif.

Pada konsentrasi ekstrak 100\% kadar abu semakin meningkat. Peningkatan ini terjadi karena belum banyaknya ekstrak belimbing wuluh sebagai aktivator belum bereaksi mengikat silika dan logam-logam lainnya. Kadar abu naik turun seiring dengan peningkatan konsentrasi ekstrak belimbing wuluh. Ketika konsentrasi ekstrak 25\% kadar abu turun, kadar abu naik saat konsentrasi 50\%, pada konsentrasi $75 \%$ kadar abu turun kembali, dan pada konsentrasi ekstrak $100 \%$ kadar abu naik kembali. Akan tetapi kadar abu yang tertinggi terdapat pada konsentrasi $50 \%$ dibanding $100 \%$. Peningkatan kadar abu terjadi karena banyaknya senyawa anorganik pada sisa pembakaran. Senyawa anorganik tersebut dihasilkan dari belimbing wuluh yang bereaksi dengan silika dan kapur pada arang aktif membentuk slag atau terak.

Arang aktif dengan fixed carbon terendah dihasilkan dari konsentrasi ekstrak $50 \%$ dengan waktu aktivasi selam 4 jam yaitu sebesar $75,96 \%$. Sedangkan kadar fixed carbon tertinggi terdapat pada konsentrasi ekstrak 100\% dengan waktu aktivasi 8 jam, yaitu sebesar $86,30 \%$. Semakin tinggi kadar fixed carbon maka luas permukaan arang aktif akan semakin besar sehingga dapat meningkatkan daya serapnya. kadar fixed carbon diperoleh dari selisih total bahan dengan kadar air, kadar volatile matter, dan abu yang tersisa pada bahan.

Fixed carbon menunjukan jumlah karbon murni yang terdapat dalam arang aktif. Arang yang telah diaktifkan memiliki kandungan karbon murni lebih besar dari arang yang tidak diaktifkan. Hal ini disebabkan pada proses karbonisasi ampas tebu belum menjadi arang secara sempurna sedangkan saat proses aktivasi suhu $900^{\circ} \mathrm{C}$ arang tersebut telah berubah menjadi arang sepenuhnya.

Berdasarkan hasil penelitian diketahui bahwa fixed carbon yang dihasilkan dari seluruh aktivasi yang dilakukan telah memenuhi Standar Industri Indonesia (SII 0258-88), yaitu minimum $65 \%$ berat jenis serbuk. Semakin tinggi konsentrasi ekstrak belimbing wuluh maka semakin meningkat kadar fixed carbon. Peningkatan fixed carbon disebabkan kadar moisture total, volatile matter dan ash yang ada pada arang aktif rendah, sehingga fixed carbon yang ada pada arang aktif meningkat. Sebaliknya jika kadar moisture total, volatile matter dan ash tinggi, maka fixed carbon menurun.

Daya adsorbsi arang terhadap lodium $\left(I_{2}\right)$ adalah untuk melihat kemampuan arang dalam menyerap molekul dengan berat molekul kecil. Penyerapan terhadap iodium dapat menunjukan banyaknya pori berukuran mikro pada permukaan arang aktif. Molekul iodium akan terserap dan menempel pada pori mikro. Semakin besar bilangan iodin menunjukan bahwa semakin banyak dan terbuka pori mikro yang terdapat pada arang aktif tersebut, hal ini 
menunjukan bahwa kualitas arang aktif tersebut semakin baik. Dari hasil penelitian untuk arang aktif dengan bilangin iodium terendah terdapat pada konsentrasi ekstrak $25 \%$ dengan waktu aktivasi selam 16 jam yaitu sebesar $801,475 \%$. Sedangkan untuk arang aktif dengan kadar iodium tertinggi terdapat pada konsentrasi ekstrak $100 \%$ dengan waktu aktivasi selama 4 jam dan konsentrasi ekstrak $75 \%$ dengan waktu aktivasi selama 4 jam sebesar 937,96\%. Hal ini sejalan dengan penelitian Setiawati et al. (2010), yang menyatakan bahwa perlakuan jenis bahan aktivator dan variasi konsentrasinya berpengaruh sangat nyata terhadap daya serap iodium. Semakin besar konsentrasi bahan aktivator, semakin besar pula daya serap terhadap iodium (Setiawati dan Suroto, 2010).

Diketahui bahwa bilangan iodin arang aktif yang dihasilkan dari seluruh variasi yang dilakukan, telah memenuhi Syarat Industri Indonesia (SII 0258-88), yaitu harus lebih besar dari $750 \mathrm{mg} / \mathrm{g}$ untuk jenis serbuk. Hal ini menunjukan bahwa pengaktifan arang ampas tebu menggunakan buah belimbing wuluh sangat reaktif sehingga memenuhi standar bilangan iodin.

Dari hasil perhitungan konsentrasi aktivator dan waktu aktivasi terhadap daya serap lodium didapat hasil rata-rata konsentrasi $100 \%$ yaitu $924,168 \mathrm{mg} / \mathrm{g}$, daya serap iodium lebih baik dibandingkan dengan konsentrasi ekstrak 25\%, $50 \%$, dan $75 \%$. Kadar daya serap iodium tertinggi saat aktivasi 4 jam, sehingga waktu aktivasi tidak perlu sampai 24 jam. Kenaikan daya serap iodium seiiring dengan kenaikan konsentrasi ekstrak belimbing wuluh. Hal ini disebabkan pada suhu aktivasi $900^{\circ} \mathrm{C}$, semakin banyak ekstrak belimbing wuluh yang bereaksi mengikat silika dan kapur sehingga gas yang mudah menguap semakin banyak dan arang aktif terbebas dari tar dan abu yang menutupi pori-pori.

Hasil statistik menunjukkan bahwa perlakuan konsentrasi terbaik diperoleh pada konsentrasi $100 \%$ untuk Moisture dengan mean 3,87\% (2,96-5,05\%). Pada Inhern Moisture konsentrasi terbaik diperoleh pada konsentrasi 50\% dengan mean 0,45\% (0,3-0,6\%). Untuk Volatile Matter konsentrasi terbaik diperoleh pada konsentrasi $100 \%$ dengan mean $7,82 \%(6,88-8,42 \%)$. Pada
Ash konsentrasi terbaik diperoleh pada konsentrasi 25\% dengan mean 3,18\% (3,113,27\%). Untuk Fixed Carbon konsentrasi terbaik diperoleh pada konsentrasi $100 \%$ dengan mean 85,36\% (84,75-86,30\%). Dari hasil tersebut menunjukan ada pengaruh konsentrasi terhadap arang aktif.

Hasil ini sejalan dengan penelitian Lestari et.al (2016) yang menyatakan bahwa semakin bertambah konsetrasi aktivator akan membuat kadar air semakin kecil, konsentrasi aktivator membuat kandungan air yang ada dalam poripori karbon akan lepas sehingga semakin luaslah permukaan karbon aktif. Konsentrasi aktivator memberikan pengaruh pada proses aktivasi, yaitu semakin tinggi konsentrasi aktivator, semakin besar pula pengaruhnya untuk mengikat senyawa-senyawa tar keluar melewati rongga atau pori-pori dari karbon aktif, sehingga volume pori semakin luas. Kondisi itulah yang menyebabkan daya serapnya menjadi semakin besar (Lestari et al., 2016; Meisrilestari et al., 2013).

Pada waktu aktivasi, Moisture Total terbaik diperoleh pada waktu aktivasi selama 8 jam dengan mean 3,97\% (2,96-5,61\%). Untuk Inhern Moisture diperoleh pada waktu aktivasi selama 8 jam dengan mean 0,425\% (0,4\%-0,5\%). Pada Volatile Matter waktu aktivasi terbaik diperoleh pada waktu aktivasi 4 jam dengan mean $12,12 \%$ (6,88\%-15,95\%). Untuk Ash waktu aktivasi terbaik diperoleh pada waktu aktivasi 8 jam dengan mean 5,64\% (3,22-8,16\%). Pada Fixed Carbon waktu aktivasi terbaik terdapat pada waktu aktivasi 4 jam dengan mean 81,84\% (75,96-85,57\%). Dari hasil tersebut terlihat bahwa tidak ada pengaruh waktu aktivasi terhadap arang aktif.

Pada Kruskal-Wallis Test, untuk variasi konsentrasi ekstrak terbaik, pada Moisture Total adalah pada konsentrasi $75 \%$ dengan mean $5,25 \%$. Untuk Inhern terdapat pada konsentrasi ekstrak 50\% dengan mean 6.38\%. Pada Volatile Matter terdapat pada konsentrasi ekstrak 100\% dengan mean $2.50 \%$. Untuk Ash terdapat pada konsentrasi ekstrak 25\% dengan mean 2,50\%. Pada Fixed Carbon konsentrasi terdapat pada konsentrasi ekstrak $100 \%$ dengan mean $14 \%$. Dari hasil tersebut menunjukan ada pengaruh konsentrasi terhadap arang aktif. 
Pada Kruskal-Wallis Test, untuk variasi waktu aktivasi terbaik, pada Moisture Total terdapat pada waktu aktivasi 8 jam dengan mean $7 \%$. Untuk Inhern waktu aktivasi terdapat pada 8 jam dengan mean 4,75\%. Pada Volatile Matter terdapat pada waktu aktivasi 4 jam dengan mean $7,75 \%$. Untuk Ash terdapat pada waktu aktivasi 8 jam dengan mean $8 \%$. Pada Fixed Carbon terdapat pada waktuaktivasi 4 jam dengan mean 9,25\%. Dari hasil tersebut terlihat bahwa tidak ada pengaruh waktu aktivasi terhadap arang aktif.

\section{SIMPULAN}

Belimbing wuluh (Averrhoa bilimbi L.) baik digunakan sebagai aktivator pada pembuatan arang aktif karena banyak mengandung senyawa asam (asam alifatik, asam heksadekanoat, asam (Z)-9-oktadekanoat, feroxida dan sulfat) yang ada didalamnya berasal dari bahan alami yang ramah lingkungan sehingga tidak berdampak pada pencemaran dan harganya murah.

Pemanfaatan arang aktif dari limbah ampas tebu menggunakan aktivator belimbing wuluh dapat mengurangi hasil samping yang sangat banyak dan berlimpah dari pabrik-pabrik gula. Aktivator belimbing wuluh berpengaruh terhadap daya serap iodium dan hasil analisisnya telah memenuhi Standar Nasional Indonesia (SNI 06-3730-1995). Selain pengujian dengan bilangan iodin, perlu juga dilakukan analisa methilen biru klorida untuk mengetahui luas permukaan arang aktif.

\section{DAFTAR PUSTAKA}

Al Kholif, M., Sugito, S., Pungut, P., dan Sutrisno, J. (2020). Kombinasi Tray Aerator Dan Filtrasi Untuk Menurunkan Kadar Besi ( $\mathrm{Fe}$ ) Dan Mangan (Mn) Pada Air Sumur. ECOTROPHIC: Jurnal Ilmu Lingkungan (Journal of Environmental Science), 14(1), Hal. 28-36. https://doi.org/10.24843/EJES.2020.v14.i01.p03

Amie, N. L. L., dan Nugraha, A. (2014). Pemanfaatan Limbah Ampas Tebu Melalui Desain Produk Perlengkapan Rumah. Jurnal Tingkat Sarjana Senirupa Dan Desain, 1, Hal. 1-7.

Bansal, R. C., Donnet, J. B., Stoeckli, F., dan Dekker, M. (1990). Carbon Aktif. Journal of Dispersion Science and Technology, 11(3). https://doi.org/https://doi.org/10.1080/0193269 9008943255

Dedy. (2010). Pembuatan Arang Aktif Dari Batang
Jagung Menggunakan Aktivator Asam Sulfat Dan Penggunaannya Pada Penjerapan Ion

Tembaga (Ii). Universitas Mataram.

Edhi, S. (2005). Budi Daaya Tanaman Tebu (Bumi Aksar).

Evival, R. (2018). Perkebunan Tebu. Graha Ilmu.

Fahrurozi, M. A., Harahap, S., dan Budijono. (2015).

The Effectiveness of Al2SO4, $\mathrm{CaO}$ and Crude

Tannin Extract Originated From Averrhoa bilimbi Leaf to Improve the Quality of Peat Water. Jom, 3(2), Hal 1-7. https://doi.org/10.11164/jjsps.16.4_704_3

Gita, G. (2012). Krisis_Air_Bersih_di. In ePrints@UNY Lumbung Pustaka Universitas Negeri Yogyakarta. Universitas Negeri Yogyakarta. https://eprints.uny.ac.id/5485/

Khimayah. (2015). Variasi Diameter Zeolit untuk Menurunkan Kada Besi ( $\mathrm{Fe}$ ) pada Air Sumur Gali. Journal of Chemical Information and Modeling, 3(1), Hal. 523-534. https://doi.org/10.1017/СBO9781107415324.00 4

Lestari, S. R. D., Sari, D. K., Rosmadiana, A., dan Dwipermata, B. (2016). Pembuatan dan Karakterisasi Karbon Aktif tempurung Kelapa dengan Aktivator Asam Fosfat Serta Aplikasinya Pada Pemurnian Minyak Goreng Bekas. Jurnal Teknika, 12(3), Hal. 419-430.

Meisrilestari, Y., Khomaini, R., dan Wijayanti, H. (2013). Pembuatan Arang Aktif Dari Cangkang Kelapa Sawit Dengan Cara Fisika, Kimia dan Fisika-Kimia. Konversi, 2(1), Hal. 46-51.

Prihatin, R. B. (2013). problem Air Bersih di Perkotaan. Info Singkat Kesejahteraan Sosial, $V(07)$, Hal. 9-12.

Purwonugroho, N. (2013). Keefektifan Kombinasi Media Filter Zeolit dan Karbon Aktif dalam Menurunkan Kadar Besi (Fe) dan AMngan (Mn) pada Air Sumur. In Universitas Muhammadiyah Surakarta.

Rasman, R., dan Saleh, M. (2016). Penurunan Kadar Besi ( $\mathrm{Fe})$ Dengan Sistem Aerasi dan Filtrasi Pada Air Sumur Gali (Eksperimen). HIGIENE: Jurnal Kesehatan Lingkungan, 2(3), Hal. 159-167. http://journal.uinalauddin.ac.id/index.php/higiene/article/view/1 826

Reza, N., Anristiani, R., dan Mursilah, S. (2013). Sari Pati Belimbing Wuluh (Averrhoa billimbi) sebagai Penjaga Mutu Buah. SMA Negeri 1 Lebak, Rangkasbitung.

Rizkyi, I. P., Budi, E., dan Susilaningsih, E. (2016). Aktivasi Arang Tongkol Jagung Menggunakan 
$\mathrm{HCl}$ Sebagai Adsorben lon Cd (II). IJCS -

Indonesia Journal of Chemical Science, 5(2).

Sahara, E., Dahliani, N. Ka., dan Manuaba, I. B. P. (2017). Pembuatan dan Karakterissasi Arang Aktif dari Batang Tanaman Gumitir (Tagetes erecta) dengan Aktivator $\mathrm{NaOH}$. Jurnal Kimia, 11(2), Hal 174-180.

Setiawati, E., dan Suroto, S. (2010). Pengaruh Bahan Aktivator Pada Pembuatan Karbon Aktif Tempurung Kelapa. Jurnal Riset Industri Hasil Hutan, 2(1), Hal. 21-26. https://doi.org/10.24111/jrihh.v2i1.911

Standar Industri Indonesia. (1988). Mutu dan Uji Arang Aktif. 0258-88. Departemen Perindustrian. R.I.

Standar Nasional Indonesia. (1995). Persyaratan Arang Aktif. (SNI) 06-730-1995.

Suhendra, D., dan Gunawan, E. R. (2011). Pembuatan Arang Aktif Dari Batang Jagung Menggunakan Aktivator Asam Sulfat Dan Penggunaannya Pada Penjerapan Ion Tembaga (li). MAKARA of Science Series, 14(1), Hal. 22-26. https://doi.org/10.7454/mss.v14i1.483
Susanti, I. K. (2005). Pembuatan Arang Aktif dari Tempurung Kelapa Sawit dengan Aktifator Na2SO4. Universitas Lampung.

Thomas, A. N. S. (2007). Tanaman Obat Tradisional 2. Kanisius, Yogyakarta.

Utassia, C. F., Prayogo, T. B., dan Rubiantoro, P. (2015). Pemanfaatan Zeolit Alam dan Tanaman Papyrus Payung Guna Menurunkan Kadar Logam Besi (Fe) dan Mangan (Mn) pada Air Limbah Kulit di Sukun Malang. http://pengairan.ub.ac.id/s1/wpcontent/uploads/2016/01/Pemanfaatan-ZeolitAlam-dan-Tanaman-Papyrus-Payung-GunaMenurunkan-Kadar-Logam-Besi-Fe-danMangan-Mn-pada-Air-Limbah-Kulit-di-SukunMalang_Cloudia-FichaUtassia_125060401111004.pdf Yulianti, A., Taslimah, dan Sriatun. (2010). Pembuatan Arang Aktif Tempurung Kelapa Sawit untuk Pemucatan Minyak Goreng Sisa Pakai. Jurnal Kimia Sains Dan Aplikasi, 13(2), Hal. 36-40. 